\title{
Effects of Feeding Silage and Grain from Glyphosate-Tolerant or Insect-Protected Corn Hybrids on Feed Intake, Ruminal Digestion, and Milk Production in Dairy Cattle ${ }^{1,2}$
}

\author{
S. S. Donkin*, J. C. Velez*, A. K. Totten*, E. P Stanisiewski†, and G. F. Hartnell† \\ *Department of Animal Sciences, Purdue University, West Lafayette, IN 47907 \\ †Monsanto Company, St. Louis, MO, 63167
}

\begin{abstract}
Lactating dairy cows were used to determine effects of feeding glyphosate-tolerant or insect-protected corn hybrids on feed intake, milk production, milk composition, and ruminal digestibility. Corn resistant to European corn borer (Ostrinia nubilalis) infestation (BtMON810), or its nontransgenic control (Bt-CON), were planted in alternating fields during two successive years. One-half of each strip was harvested for whole plant corn silage and the remainder was allowed to mature and harvested as grain. Effects of feeding diets containing either Bt-MON810 or Bt-CON grain and silage were determined in two experiments (1 and 2) conducted during successive years. In experiment 3 , glyphosate-tolerant Roundup Ready corn (RR-GA21) or its nontransgenic control (RR-CON) corn were grown in alternating fields during one cropping season. Diets contained 42 to $60 \%$ corn silage and 20 to $34 \%$ corn grain from Bt-MON810, RR-GA21, or the appropriate nontransgenic counterpart; treatments were applied using a switchback design. Cows were fed ad libitum and milked twice daily. There were no differences for nutrient composition between silage sources or between grain sources within an experiment. Data for experiments 1 and 2 indicated similar dry matter intake (DMI), 4\% fat-corrected milk (FCM) production, and milk composition between Bt-MON810 and Bt-CON diets. There were no differences for DMI, 4\% FCM production, and milk composition between RR-GA21 and $\mathrm{RR}$-CON diets. There was no difference in ruminal degradability, determined separately for corn silage and corn grain, for RR-GA21 or Bt-MON810-hybrids compared with their respective controls. These data demon-
\end{abstract}

\footnotetext{
Received August 26, 2002.

Accepted December 27, 2002.

Corresponding author: S. S. Donkin; e-mail: sdonkin@purdue.edu.

${ }^{1}$ Mention of trade name does not constituted endorsement by Purdue University.

${ }^{2}$ Supported in part by funds from the Indiana Agricultural Research Programs (paper \#16,867) as a contribution to North Central Regional Project NC-185 and by Monsanto Company, St. Louis, MO.
}

strate equivalence of nutritional value and production efficiency for corn containing Bt-MON810 compared with its control and for RR-GA21 corn compared with its control.

(Key words: genetically modified, Roundup Ready, YieldGard corn, herbicide tolerant)

Abbreviation key: Bt $=$ Bacillus thuringiensis, BtCON = non-transgenic control corn, Bt-MON810 = corn resistant to European corn borer (Ostrinia nubilalis) infestation, ERD = estimated ruminal disappearance, $\mathbf{R R}=$ Roundup Ready, RR-GA21 = glyphosate tolerant Roundup Ready corn, RR-CON = nontransgenic control corn.

\section{INTRODUCTION}

Genetic engineering of plants has enabled the horizontal transfer of genes that impart specific traits to the recipient plant such as herbicide tolerance, viral resistance, insect pest resistance, and modifications in nutrient profile. Commercialization of this technology is a highly regulated process involving the US FDA, US Department of Agriculture, and the Environmental Protection Agency (reviewed by Adkisson et al., 2000). The development and use of transgenic crops has been the subject of mounting scientific discussion, public debate, scrutiny, and concern. The use of genetically modified corn hybrids that express herbicide, insect, or nutritional modifications has been a central part of these exchanges. There has been considerable focus on issues related to direct consumption of transgenic crops in human diets. Concerns have also been expressed regarding the safety of using transgenic plants in diets of food-producing animals (Beever and Kemp, 2000).

Corn hybrids genetically enhanced to express proteins that are native to the Bacillus thuringiensis (Bt) bacterium, commonly referred to as Bt-corn hybrids, are resistant to damage caused by European corn borer (Ostrinia nubilalis) infestation (Koziel et al., 1993). Bacillus thuringiensis is a soilborne bacterium that produces crystalline proteins in the form of protoxins. When consumed by the larval stage of the European 
corn borer and other insects, the crystalline proteins are activated and bind to the lining of the gut causing cellular swelling and lysis due to osmotic balance disruption (Feitelson et al., 1992). Expression of the crystalline protein gene in corn hybrids provides protection against European corn borer infestation (Koziel et al., 1993; Peferoen, 1997; Rice and Pilcher, 1998).

The effect of feeding corn resistant to European corn borer infestation (Bt-MON810) to dairy cattle has not been investigated extensively (Clark and Ipharraguerre, 2001). In an early study (Faust and Miller, 1997), lactating Holsteins fed rations containing green chop from either Bt hybrids or non-Bt corn for $14 \mathrm{~d}$ produced the same amount of milk. Mayer and Rutzmoser (1999) fed rations containing Bt or non-Bt corn silage to Fleckvieh cattle in Germany. Silage feeding value and cattle performance was not different between the hybrids. No differences were detected for rumen fermentation characteristics (in situ NDF digestibility, rumen VFA concentration, rumen $\mathrm{pH}$ ), DMI, milk production, efficiency of milk production, or milk composition when cows were fed $\mathrm{Bt}$ and non-Bt diets in a shortterm trial (Folmer et. al., 2002). In a recent study (Barriere et. al., 2001), two groups of lactating Holstein cows were fed silage from either Bt or non-Bt hybrids for 13 wk and BW, FCM, milk protein, and milk fat were not affected by corn hybrid, although cows fed Bt silage had higher intakes than controls.

Roundup Ready (RR) corn and soybeans, which are modified to provide tolerance to effects of the herbicide Roundup (Monsanto Company, St. Louis, MO), offers crop and livestock producers with an alternative strategy in managing weed pressure, but the effects of feeding RR corn on animal production have not been fully evaluated. Differences in corn yield per hectare using $R R$ hybrids are relatively easy to determine, but differences in feeding value that may exist as a secondary consequence of pest resistance are less apparent. The feeding value of the resulting grain and silage may be altered directly or as a consequence of controlling insects and disease in the crop. Such changes may affect the efficiency of whole farm nutrient utilization in integrated plant and animal production systems.

The primary objectives of our experiments were to assess the effects of feeding silage and grain prepared from transgenic corn on feed intake, milk production, and DM digestibility in lactating dairy cows. Transgenic corn hybrids were compared with silage and grain from their near-isogenic control corn hybrids grown and harvested under identical conditions. The effects of feeding Bt-MON810 and glyphosate-tolerant Roundup Ready corn (RR-GA21) were tested in separate studies that utilized both silage and grain derived from the transgenic corn or the respective control.

\section{MATERIALS AND METHODS}

Two trials (experiment 1 and 2) were conducted in successive years (1998 to 1999) to evaluate the effects of feeding Bt-MON810 and the nontransgenic control (Bt-CON) corn grain and silage on milk production, milk composition, and ruminal digestibility in lactating dairy cows. For Roundup Ready corn, a single trial (Experiment 3) was conducted using corn silage and corn grain harvested from one growing season (1999) for RRGA21 corn and nontransgenic control (RR-CON) corn. All trials were conducted using a switchback design with a minimum period length of $21 \mathrm{~d}$. Protocols for cow care and use were approved by the Purdue University Animal Care and Use Committee.

\section{Agronomics}

During the 1998 cropping year, alternating quarters of a 54.8-ha field were planted with Bt-MON810 (Pioneer HIBRED International, Des Moines, IA, 34RO6, event MON810) and Bt-CON (Pioneer HIBRED International, Des Moines, IA, 3489) in 6.85-ha units. Perimeter rows corresponding to at least $18 \mathrm{~m}$ wide were removed and half of each strip was harvested for whole plant corn silage; the remainder of the crop was allowed to mature and later harvested as grain. Corn was harvested for silage at the $1 / 3$ to $2 / 3$ milk line or approximately $40 \% \mathrm{DM}$ and stored in $4.3 \times 15.2$ meter upright silos. During the following cropping year (1999), 41 ha of the same field was planted with either Bt-MON810 (Pioneer HIBRED International, Des Moines, IA, 34F80BT) or Bt-CON (Pioneer HIBRED International, Des Moines, IA, 34E79) in alternating 6.83-ha units. Corn was harvested as silage and grain as described above.

During the 1999 cropping year alternating quarters of a 20.25-ha field were planted with either corn modified with RR-GA21 (DK626RR, event GA21, Dekalb, IL) or RR-CON (DK626, Dekalb, IL). Glyphosate herbicide was applied to RR-GA21 plants as Roundup Ultra (Monsanto Company, St. Louis, MO) at a rate of $2.3 \mathrm{~L} / \mathrm{ha}$. Balance WDG (Aventis CropScience USA LP, Research Triangle Park, NC) and Atrazine (Ciba-Geigy Corp., Greensboro, NC) herbicides were applied to RR-CON corn plants at 140 and $1.67 \mathrm{~kg} / \mathrm{ha}$, respectively. Perimeter rows equal to at least $18 \mathrm{~m}$ of width were removed and half of each strip was harvested for whole plant corn silage; the remainder of the crop was allowed to mature and later harvested as grain. Corn was harvested for silage at the $1 / 3$ to $2 / 3$ milk line or 36 to $38 \%$ DM. 
Table 1. Ingredients and nutrient composition of diets derived from Bt-MON810 and its non-transgenic control corn (Bt-CON).

\begin{tabular}{|c|c|c|c|c|}
\hline \multirow[b]{2}{*}{ Item } & \multicolumn{2}{|c|}{ Experiment 1} & \multicolumn{2}{|c|}{ Experiment 2} \\
\hline & Bt-MON810 & Bt-CON & Bt-MON810 & Bt-CON \\
\hline \multicolumn{5}{|l|}{ Ingredient $^{1}$} \\
\hline Corn silage (MON810) & 41.8 & & 59.6 & \\
\hline Corn silage (Bt-CON) & & 41.8 & & 59.6 \\
\hline Cracked corn (MON810) & 34.1 & & 19.9 & \\
\hline Cracked corn (Bt-CON) & & 34.1 & & 19.9 \\
\hline Soybean meal & 16.1 & 16.1 & 13.5 & 13.5 \\
\hline Aminoplus $^{2}$ & 4.4 & 4.4 & 4.0 & 4.0 \\
\hline Urea & 0.11 & 0.11 & 0.18 & 0.18 \\
\hline Potassium chloride & 0.16 & 0.16 & 0.28 & 0.28 \\
\hline Magnesium oxide & 0.16 & 0.16 & $\ldots$ & $\ldots$ \\
\hline Limestone & 0.90 & 0.90 & 0.89 & 0.89 \\
\hline Dicalcium phosphate & 0.37 & 0.37 & 0.71 & 0.71 \\
\hline Sodium bicarbonate & 0.49 & 0.49 & 0.79 & 0.79 \\
\hline Trace mineral salt ${ }^{3}$ & 0.08 & 0.08 & 0.09 & 0.09 \\
\hline Selenium $^{4}$ & 0.02 & 0.02 & 0.02 & 0.02 \\
\hline Vitamin mineral premix ${ }^{5}$ & 0.01 & 0.01 & 0.01 & 0.01 \\
\hline Vitamin E premix 6 & 0.01 & 0.01 & 0.01 & 0.01 \\
\hline \multicolumn{5}{|l|}{ Chemical composition ${ }^{7}$} \\
\hline $\mathrm{CP}$ & 20.0 & 18.2 & 17.9 & 17.0 \\
\hline $\mathrm{ADF}$ & 13.9 & 13.8 & 16.0 & 14.5 \\
\hline $\mathrm{NDF}$ & 25.9 & 24.8 & 26.2 & 25.0 \\
\hline $\mathrm{NE}_{\mathrm{L}}, \mathrm{Mcal} / \mathrm{kg} \mathrm{DM}$ & 1.71 & 1.74 & 1.72 & 1.74 \\
\hline $\mathrm{Ca}$ & 0.88 & 0.81 & 0.89 & 0.71 \\
\hline $\mathrm{P}$ & 0.52 & 0.51 & 0.51 & 0.47 \\
\hline
\end{tabular}

${ }^{1}$ Amounts are as percentages of DM unless indicated otherwise.

${ }^{2}$ Processed soybean meal, (RUP $=58 \%$ ); Consolidated Nutrition L. C., trademark.

${ }^{3}$ Composition: $36.6 \% \mathrm{Na}, 56.4 \% \mathrm{Cl}, 70 \mathrm{mg} / \mathrm{kg}$ of Co, $350 \mathrm{mg} / \mathrm{kg}$ of Cu, $1750 \mathrm{mg} / \mathrm{kg}$ of $\mathrm{Fe}, 70 \mathrm{mg} / \mathrm{kg}$ of I, $2800 \mathrm{mg} / \mathrm{kg}$ of $\mathrm{Mn}, 3500 \mathrm{mg} / \mathrm{kg}$ of $\mathrm{Zn}$.

${ }^{4}$ Composition: $30 \% \mathrm{Ca}, 600 \mathrm{mg} / \mathrm{kg}$ of Se.

${ }^{5}$ Composition: $14 \% \mathrm{Mg}, 16,500 \mathrm{mg} / \mathrm{kg}$ of $\mathrm{Cu}, 48,000 \mathrm{mg} / \mathrm{kg}$ of $\mathrm{Mn}, 340 \mathrm{mg} / \mathrm{kg}$ of Se, $53,000 \mathrm{mg} / \mathrm{kg}$ of Zn, $6,600,000 \mathrm{IU} / \mathrm{kg}$ vitamin A, 2,200,000 IU/kg vitamin D, 23,000 IU/kg vitamin $\mathrm{E}$.

${ }^{6}$ Vitamin E (44,000 IU/kg).

${ }^{7}$ Based on analysis of composite samples of TMR.

\section{Animals, Experimental Design, and Diets}

Experiment 1: Bt-MON810 year 1. Twelve midlactation multiparous dairy cattle selected from the Purdue Dairy Research and Education Center were stratified by milk produced during the previous lactation and assigned randomly to one of two treatment groups. Cows were housed in individual tie stalls and were fed a TMR once daily ad libitum. Animals were fed diets containing corn silage and corn grain from either Bt-MON810 or Bt-CON (Table 1). Treatments were applied as a switchback design in three 21-d periods. Six cows received the treatment series BtMON810, Bt-CON, and Bt-MON810 and six cows received the series Bt-CON, Bt-MON810, and Bt-CON. The first $14 \mathrm{~d}$ of each period were used for adaptation to treatment and the last $7 \mathrm{~d}$ used to determine effects of treatments on feed intake, milk yield, and milk composition.

Cows were milked twice daily and individual milk yields were recorded electronically at each milking
(HerdMaster Galaxy Management System, Alfa-Laval Agri Inc., St. Louis, MO). Milk samples were obtained for each milking during the last $7 \mathrm{~d}$ of each period and analyzed for milk fat, milk protein, lactose, SNF, and SCC by infrared analysis at the Indiana State Dairy Association milk testing laboratory (West Lafayette, IN). Feed offered and feed refusals were measured daily for each cow. Samples of the rations were collected once per week and matter was determined for each ration by drying samples in a convection oven at $55 \mathrm{C}$ for 48 h. Dry matter intake was determined by difference for feed offered and feed refused assuming equal DM content of feed issued and refused.

Experiment 2: Bt-MON810 year 2. Sixteen multiparous midlactation Holstein cows were assigned randomly to one of two treatment groups, and managed as described for experiment 1 . Cows were fed diets (Table 1) containing corn silage and corn grain from either a Bt-MON810 (Pioneer HIBRED International 34F80Bt) or the Bt-CON counterpart hybrid line (Pioneer HIBRED International 34E79). The experiment was con- 
ducted as a three-period switchback design. The duration of each period was $28 \mathrm{~d}$, which included $14 \mathrm{~d}$ of adaptation followed by $14 \mathrm{~d}$ to determine effect of treatments on feed intake, milk yield, and milk composition (DHIA, East Lansing, MI). Dry matter intake was determined as described for experiment 1 . Body weight was measured at the beginning and end of each period, and BW change was determined by difference for each cow within each period. Body condition scores were measured (Wildman et al., 1982) by two trained investigators using a five-point scale where $1=$ thin and $5=$ obese. Measurements were obtained on the day immediately before the start of the first period and on the last day of each period. Change in BCS was determined by difference for each cow within each period.

Experiment 3: RR-GA21 corn. The experiment was conducted as a three-period switchback design. The duration of each of the periods was $28 \mathrm{~d}$, with the first 14 $\mathrm{d}$ used for adaptation to treatment, followed by $14 \mathrm{~d}$ to determine effects of treatment on feed intake, milk yield, and milk composition. Twelve noncannulated and four rumen cannulated multiparous midlactation Holstein cows were assigned randomly within cannulated and noncannulated blocks to one of two treatment groups. Cows were housed in individual tie stalls and were fed a TMR once daily ad libitum. Feed offered and feed refusals were measured daily for each cow, and DMI was determined as described above for experiment 1. Cows were fed diets (Table 2) containing silage and grain from either RR-GA21 for (DK626RR, Dekalb, IL) or RR-CON (DK626, Dekalb, IL) hybrids. Corn silage and grain were analyzed for nutrient composition before the initiation of the experiment and at the end of each experimental period. Intake, milk production, milk composition, BW change, and BCS change were determined as described for experiment 2 .

\section{Feed Sampling and Analysis}

Samples of feedstuffs were collected at the beginning of each period, and the conclusion of the experiment and analyzed for nutrient composition by wet chemistry methods at a commercial laboratory (Dairy One, DHI Forage Testing Lab, Ithaca, NY). Samples of diets were collected weekly during the experiment, and a composite sample formed for each treatment diet was analyzed at the commercial laboratory indicated above.

\section{Ruminal Digestibility Measurements}

Ruminal digestibility measures for RR-GA21 for (DK626RR, Dekalb, IL) or RR-CON (DK626, Dekalb, IL) silage and grain were determined as part of experiment 3 . During the final $72 \mathrm{~h}$ of each period of experi-
Table 2. Ingredients and nutrient composition of diets derived from glyphosate tolerant (RR-GA21) and its non-transgenic control corn (RR-CON).

\begin{tabular}{|c|c|c|}
\hline Item & RR-GA21 & $\mathrm{RR}-\mathrm{CON}$ \\
\hline \multicolumn{3}{|l|}{ Ingredient $^{1}$} \\
\hline Corn silage (RR-GA21) & 59.6 & \\
\hline Corn silage (RR-CON) & & 59.6 \\
\hline Cracked corn (RR-GA21) & 19.9 & \\
\hline Cracked corn (RR-CON) & & 19.9 \\
\hline Soybean meal & 13.5 & 13.5 \\
\hline Aminoplus $^{2}$ & 4.0 & 4.0 \\
\hline Urea & 0.18 & 0.18 \\
\hline Potassium chloride & 0.28 & 0.28 \\
\hline Limestone & 0.89 & 0.89 \\
\hline Dicalcium phosphate & 0.71 & 0.71 \\
\hline Sodium bicarbonate & 0.79 & 0.79 \\
\hline Trace mineral salt ${ }^{3}$ & 0.09 & 0.09 \\
\hline Selenium ${ }^{4}$ & 0.02 & 0.02 \\
\hline Vitamin mineral premix ${ }^{5}$ & 0.01 & 0.01 \\
\hline Vitamin $\mathrm{E}$ premix ${ }^{6}$ & 0.01 & 0.01 \\
\hline \multicolumn{3}{|l|}{ Chemical composition ${ }^{7}$} \\
\hline $\mathrm{CP}$ & 16.8 & 16.9 \\
\hline $\mathrm{ADF}$ & 15.0 & 16.1 \\
\hline NDF & 25.9 & 28.8 \\
\hline $\mathrm{NE}_{\mathrm{L}}, \mathrm{Mcal} / \mathrm{kg} \mathrm{DM}$ & 0.75 & 0.75 \\
\hline $\mathrm{Ca}$ & 0.65 & 0.65 \\
\hline $\mathrm{P}$ & 0.43 & 0.43 \\
\hline
\end{tabular}

${ }^{1}$ Amounts are as percentages of DM unless indicated otherwise.

${ }^{2}$ Processed soybean meal, (RUP $=58 \%$ ); Consolidated Nutrition L. C., trademark.

${ }^{3}$ Composition: $36.6 \% \mathrm{Na}, 56.4 \% \mathrm{Cl}, 70 \mathrm{mg} / \mathrm{kg}$ of Co, $350 \mathrm{mg} / \mathrm{kg}$ of $\mathrm{Cu}, 1750 \mathrm{mg} / \mathrm{kg}$ of Fe, $70 \mathrm{mg} / \mathrm{kg}$ of I, $2800 \mathrm{mg} / \mathrm{kg}$ of $\mathrm{Mn}, 3500 \mathrm{mg} / \mathrm{kg}$ of $\mathrm{Zn}$.

${ }^{4}$ Composition: $30 \% \mathrm{Ca}, 600 \mathrm{mg} / \mathrm{kg}$ of Se.

${ }^{5}$ Composition: $14 \% \mathrm{Mg}, 16,500 \mathrm{mg} / \mathrm{kg}$ of $\mathrm{Cu}, 48,000 \mathrm{mg} / \mathrm{kg}$ of $\mathrm{Mn}$, $340 \mathrm{mg} / \mathrm{kg}$ of Se, $53,000 \mathrm{mg} / \mathrm{kg}$ of $\mathrm{Zn}, 6,600,000 \mathrm{IU} / \mathrm{kg}$ vitamin A, $2,200,000 \mathrm{IU} / \mathrm{kg}$ vitamin $\mathrm{D}, 23,000 \mathrm{IU} / \mathrm{kg}$ vitamin $\mathrm{E}$.

${ }^{6}$ Vitamin E (44,000 IU/kg).

${ }^{7}$ Based on analysis of composite samples of TMR.

ment 3, Dacron bags containing corn silage or corn grain for each treatment (DK626RR -Dekalb, IL or DK626, Dekalb, IL) were placed in the rumen of four cannulated cows. Ruminal digestibility of Bt-MON810 corn (Pioneer HIBRED International $34 \mathrm{~F} 80 \mathrm{Bt}$ ) or the Bt-CON (Pioneer HIBRED International 34E79) was determined in a separate 21 -d period that immediately followed experiment 2 and utilized four rumen-cannulated cows that were not part of the production study (experiment 2). Cows were assigned in pairs to a TMR containing either Bt-MON810 corn (Pioneer HIBRED International 34F80Bt) or the Bt-CON (Pioneer HIBRED International 34E79) and adapted to diets for 21-d before samples were placed in the rumen for digestibility measurements. Dacron bags containing corn silage or corn grain from either Bt-MON810 or Bt-CON were placed in the rumen during the following 72-h period.

The rate of DM disappearance in the rumen was determined for silage and grain ground through a 2-mm screen. Approximately $5 \mathrm{~g}$ of feed was placed into 10- 
Table 3. Chemical composition and estimated ruminal disappearance of feedstuffs associated with BtMON810 and its control.

\begin{tabular}{|c|c|c|c|c|}
\hline \multirow[b]{2}{*}{ Item $^{1}$} & \multicolumn{2}{|c|}{ Silage } & \multicolumn{2}{|c|}{ Grain } \\
\hline & Bt-MON810 & Bt-CON & Bt-MON810 & Bt-CON \\
\hline \multicolumn{5}{|l|}{ Experiment 12} \\
\hline $\mathrm{DM}$ & $43.3 \pm 2.1$ & $41.0 \pm 0.3$ & $86.4 \pm 0.1$ & $86.4 \pm 0.1$ \\
\hline $\mathrm{CP}$ & $7.8 \pm 0.3$ & $7.9 \pm 0.1$ & $8.6 \pm 0.3$ & $9.15 \pm 0.1$ \\
\hline $\mathrm{ADF}$ & $25.2 \pm 0.5$ & $25.2 \pm 2.4$ & $3.4 \pm 0.7$ & $2.9 \pm 0.6$ \\
\hline $\mathrm{NDF}$ & $41.5 \pm 1.3$ & $43.2 \pm 1.1$ & $8.7 \pm 2.1$ & $9.3 \pm 0.3$ \\
\hline NSC & $42.5 \pm 1.6$ & $40.5 \pm 1.0$ & $76.7 \pm 2.3$ & $75.6 \pm 0.2$ \\
\hline $\mathrm{NE}_{\mathrm{L}}, \mathrm{Mcal} / \mathrm{kg}$ & $1.61 \pm 0.02$ & $1.58 \pm 0.02$ & $2.11 \pm 0.02$ & $2.09 \pm 0.02$ \\
\hline $\mathrm{Ca}$ & $0.24 \pm 0.01$ & $0.23 \pm 0.01$ & $0.01 \pm 0.00$ & $0.01 \pm 0.00$ \\
\hline $\mathrm{P}$ & $0.21 \pm 0.01$ & $0.25 \pm 0.02$ & $0.36 \pm 0.01$ & $0.32 \pm 0.01$ \\
\hline $\mathrm{Mg}$ & $0.14 \pm 0.02$ & $0.14 \pm 0.01$ & $0.12 \pm 0.01$ & $0.11 \pm 0.01$ \\
\hline $\mathrm{K}$ & $1.11 \pm 0.02$ & $1.06 \pm 0.06$ & $0.47 \pm 0.01$ & $0.43 \pm 0.01$ \\
\hline \multicolumn{5}{|l|}{ Experiment $2^{2}$} \\
\hline DM & $38.6 \pm 1.6$ & $38.7 \pm 2.9$ & $87.7 \pm 1.8$ & $87.5 \pm 1.9$ \\
\hline $\mathrm{CP}$ & $7.9 \pm 0.6$ & $8.2 \pm 0.4$ & $9.4 \pm 0.1$ & $9.4 \pm 0.1$ \\
\hline $\mathrm{ADF}$ & $21.9 \pm 1.1$ & $21.2 \pm 1.3$ & $3.3 \pm 1.0$ & $3.4 \pm 0.7$ \\
\hline $\mathrm{NDF}$ & $36.9 \pm 3.9$ & $35.9 \pm 2.5$ & $9.7 \pm 2.5$ & $10.9 \pm 2.4$ \\
\hline NSC & $47.0 \pm 3.7$ & $48.0 \pm 3.3$ & $74.9 \pm 3.1$ & $73.6 \pm 3.3$ \\
\hline $\mathrm{NE}_{\mathrm{L}}, \mathrm{Mcal} / \mathrm{kg}$ & $1.67 \pm 0.07$ & $1.71 \pm 0.09$ & $2.07 \pm 0.02$ & $2.07 \pm 0.02$ \\
\hline $\mathrm{Ca}$ & $0.23 \pm 0.05$ & $0.24 \pm 0.04$ & $0.08 \pm 0.04$ & $0.03 \pm 0.01$ \\
\hline $\mathrm{P}$ & $0.25 \pm 0.04$ & $0.24 \pm 0.03$ & $0.35 \pm 0.02$ & $0.37 \pm 0.03$ \\
\hline $\mathrm{Mg}$ & $0.18 \pm 0.01$ & $0.20 \pm 0.01$ & $0.14 \pm 0.01$ & $0.14 \pm 0.01$ \\
\hline $\mathrm{K}$ & $0.89 \pm 0.01$ & $0.90 \pm 0.05$ & $0.38 \pm 0.04$ & $0.42 \pm 0.02$ \\
\hline $\mathrm{ERD}^{3}, \%$ & $56.2 \pm 0.7$ & $60.6 \pm 0.7$ & $71.9 \pm 3.4$ & $82.6 \pm 3.4$ \\
\hline
\end{tabular}

${ }^{1}$ Amounts are as percentages of DM unless indicated otherwise.

${ }^{2}$ Means and standard deviations $(\mathrm{n}=3)$.

${ }^{3}$ Estimated ruminal disappearance (least squared means and standard errors).

$\times 20$-cm Dacron bags of known weight with a mean pore size of $53 \mu \mathrm{m}$ (Ankom, Fairport, NY) and sealed. Before rumen incubation, the bags containing feed were soaked in $39^{\circ} \mathrm{C}$ tap water for 15 min. Triplicate bags were placed in the rumen for $72,48,24,12,6,3$, and $0 \mathrm{~h}$, removed simultaneously, and rinsed together in a bucket with cold tap water until the water ran clear (Nocek, 1988). The bags were then dried at $55^{\circ} \mathrm{C}$ for 48 $\mathrm{h}$ and weighed. Blank bags (without corn) were incubated for $72 \mathrm{~h}$ and used to correct for material entering the bags from the rumen environment. The DM present in the 0-h bags was used to correct samples for the material that was immediately solublized and washed out of the bags.

The rate of disappearance of DM was determined using the Marquardt's method in the nonlinear procedure of SAS (1999). The initial parameters were estimates by visual appraisal of the data and the parameters adjusted through an iterative procedure until the change in residual sums of squares met a convergence criterion. The mathematical model used was $R=D\left(K_{d} t\right)$, where $R=$ percentage of digestible $D M$ remaining $(t>$ $0), \mathrm{D}=$ water insoluble potentially digestible material, $\mathrm{K}_{\mathrm{d}}$ = disappearance rate constant of the insoluble material, and $\mathrm{t}=$ time. Estimated ruminal disappearance (ERD) was calculated as ERD $=\mathrm{S}+\mathrm{P}(\mathrm{Kd} /(\mathrm{Kd}+\mathrm{Kp}))$ where $\mathrm{S}$ is the soluble fraction, $\mathrm{P}$ is the potentially digestible fraction, and $\mathrm{Kp}$ is the rate of passage of feed from the rumen (Vazquez-Anon et al., 1993). The value for $\mathrm{Kp}$ was estimated at $0.06 / \mathrm{h}$ for these calculations.

\section{Statistical Analysis}

Means generated for each cow within period were analyzed using the GLM procedure of SAS (1999) to adjust for the effects of cow and period. Parameter estimates for rates of rumen digestion were obtained for each feed within cow and period using Marquardt's algorithm (Netter et al., 1985) in the nonlinear procedure of SAS and resulting estimates were analyzed by the GLM procedure of SAS. When no significant experiment by treatment interaction was observed data from the two Bt-MON810 corn trials were combined, and the effects of the experiment were accounted for as a blocking variable. Power of the test was determined (Neter et al., 1985) using the adjustments for experimental design according to Lucas (1960) and the mean squared errors generated using SAS (1999). Data are presented as least squares means and their associated standard errors unless indicated otherwise.

\section{RESULTS AND DISCUSSION}

The nutrient composition of Bt-MON810 and Bt-CON corn silage were similar within year of harvest and type 
Table 4. Effect of feeding corn silage and corn grain from Bt-MON810 corn and its nontransgenic counterpart (Bt-CON) on feed intake, milk production, and composition.

\begin{tabular}{|c|c|c|c|c|}
\hline & Bt-MON810 & Bt-CON & $\mathrm{SE}$ & $P$-value \\
\hline \multicolumn{5}{|l|}{ Experiment 11998 Crop year } \\
\hline $\mathrm{DMI}, \mathrm{kg} / \mathrm{d}^{1}$ & 23.9 & 25.4 & 0.5 & 0.06 \\
\hline $4 \%$ FCM yield, $\mathrm{kg} / \mathrm{d}$ & 34.9 & 35.7 & 0.6 & 0.35 \\
\hline Milk yield, $\mathrm{kg} / \mathrm{d}$ & 38.3 & 39.5 & 0.5 & 0.15 \\
\hline Efficiency (Milk:DMI, kg/kg) & 1.49 & 1.45 & 0.04 & 0.51 \\
\hline Milkfat, \% & 3.46 & 3.42 & 0.07 & 0.71 \\
\hline Milkfat, kg/d & 1.31 & 1.33 & 0.03 & 0.58 \\
\hline Milk protein, \% & 3.00 & 2.97 & 0.02 & 0.50 \\
\hline Milk protein, kg/d & 1.15 & 1.17 & 0.02 & 0.41 \\
\hline Milk lactose, \% & 4.66 & 4.70 & 0.02 & 0.20 \\
\hline Milk lactose, kg/d & 1.80 & 1.87 & 0.02 & 0.05 \\
\hline $\mathrm{SNF}, \%$ & 6.68 & 6.75 & 0.02 & 0.07 \\
\hline $\mathrm{SNF}, \mathrm{kg} / \mathrm{d}$ & 2.57 & 2.67 & 0.03 & 0.05 \\
\hline $\mathrm{SCC}\left(\times 10^{3}\right.$ cells $\left./ \mathrm{ml}\right)$ & 287 & 163 & 86 & 0.33 \\
\hline \multicolumn{5}{|l|}{ Experiment 21999 Crop year } \\
\hline DMI, $\mathrm{kg} / \mathrm{d}^{1}$ & 24.1 & 23.2 & 0.4 & 0.14 \\
\hline $4 \%$ FCM yield, $\mathrm{kg} / \mathrm{d}$ & 30.9 & 30.4 & 0.6 & 0.60 \\
\hline Milk yield, kg/d & 32.2 & 32.2 & 0.7 & 0.96 \\
\hline Efficiency (Milk:DMI, kg/kg) & 1.36 & 1.36 & 0.60 & 0.93 \\
\hline Milk fat, \% & 3.75 & 3.66 & 0.40 & 0.14 \\
\hline Milk fat, $\mathrm{kg} / \mathrm{d}$ & 1.03 & 1.02 & 0.02 & 0.60 \\
\hline Milk protein, \% & 3.24 & 3.19 & 0.02 & 0.19 \\
\hline Milk protein, $\mathrm{kg} / \mathrm{d}$ & 1.21 & 1.17 & 0.02 & 0.40 \\
\hline Milk lactose, \% & 4.59 & 4.56 & 0.05 & 0.74 \\
\hline Milk lactose, kg/d & 1.49 & 1.48 & 0.04 & 0.89 \\
\hline $\mathrm{SNF}, \%$ & 8.65 & 8.56 & 0.06 & 0.36 \\
\hline $\mathrm{SNF}, \mathrm{kg} / \mathrm{d}$ & 2.79 & 2.76 & 0.07 & 0.75 \\
\hline $\mathrm{SCC}\left(\times 10^{3}\right.$ cell $\left.\mathrm{s} / \mathrm{ml}\right)$ & 241 & 198 & 58 & 0.62 \\
\hline BW change, kg & 9.4 & 8.4 & 4.6 & 0.88 \\
\hline BCS change ${ }^{2}$ & 0.04 & 0.01 & 0.03 & 0.43 \\
\hline \multicolumn{5}{|c|}{ Combined 1998 and 1999 Crop years } \\
\hline DMI, kg/d & 24.1 & 24.3 & 0.4 & 0.79 \\
\hline $4 \%$ FCM yield, $\mathrm{kg} / \mathrm{d}$ & 33.2 & 33.2 & 0.5 & 0.90 \\
\hline Milk yield, kg/d & 35.2 & 35.6 & 0.5 & 0.56 \\
\hline Efficiency (Milk:DMI, kg/kg) & 1.44 & 1.41 & 0.04 & 0.63 \\
\hline Milk fat, $\%$ & 3.67 & 3.60 & 0.04 & 0.24 \\
\hline Milk fat, $\mathrm{kg} / \mathrm{d}$ & 1.18 & 1.17 & 0.02 & 0.65 \\
\hline Milk protein, \% & 3.14 & 3.10 & 0.02 & 0.12 \\
\hline Milk protein, kg/d & 1.19 & 1.18 & 0.02 & 0.78 \\
\hline Milk lactose, $\%$ & 4.64 & 4.62 & 0.04 & 0.67 \\
\hline Milk lactose, kg/d & 1.64 & 1.66 & 0.03 & 0.67 \\
\hline $\mathrm{SNF}, \%$ & 7.71 & 7.67 & 0.04 & 0.52 \\
\hline $\mathrm{SNF}, \mathrm{kg} / \mathrm{d}$ & 2.69 & 2.70 & 0.05 & 0.88 \\
\hline $\mathrm{SCC}\left(\times 10^{3}\right.$ cells $\left./ \mathrm{ml}\right)$ & 258 & 198 & 49 & 0.39 \\
\hline
\end{tabular}

${ }^{1}$ Treatment $\times$ experiment effect $(P<0.05)$.

${ }^{2}$ Units of BCS change based on a 1-point scale where $1=$ thin and $5=$ obese.

of feed (Table 3). Lack of differences between ingredients enabled direct substitution of Bt-MON810 and BtCON corn silage and corn grain without concern for altering the nutrient composition between TMR (Table 1).

There were no differences between Bt-MON810 and Bt-CON formulated diets for DMI or any other production parameter when data from the two cropping years were combined (Table 4). When data were examined separately for each year, DMI was numerically greater $(P=0.06)$ for cows fed the Bt-MON810 diet compared with Bt-CON during experiment 1 , but that pattern was reversed for experiment 2 (Table 4). There were no interaction $(P>0.05)$ for any other production variable measured. In both experiments, $4 \% \mathrm{FCM}$ yield and efficiency of $4 \%$ FCM yield were not different $(P>0.15$, Table 4). Slight differences were apparent for yield of milk components within experiment 1 , where cows fed diets with Bt-MON810 had higher $(P<0.05)$ milk lactose $(1.87 \mathrm{vs} .1 .80 \mathrm{~kg} / \mathrm{d})$ and SNF (2.67 vs. $2.57 \mathrm{~kg} / \mathrm{d})$ than those fed Bt-CON (Table 3). There were no milk component differences during experiment 2 , nor when experiments were combined. The Bt-CON hybrids differed for the two experiments but were derived from the parent lines used to create each of the Bt-hybrids evaluated. Therefore the test material and controls in 
Table 5. Nutrient composition and estimated ruminal disappearance of feedstuffs derived from glyphosate tolerant (RR-GA21) and its nontransgenic control (RR-CON) corn.

\begin{tabular}{|c|c|c|c|c|}
\hline \multirow[b]{2}{*}{ Item } & \multicolumn{2}{|c|}{ Silage } & \multicolumn{2}{|c|}{ Grain } \\
\hline & RR-GA21 & RR-CON & RR-GA21 & RR-CON \\
\hline \multicolumn{5}{|l|}{ Nutrient $^{1,2}$} \\
\hline DM & $37.3 \pm 2.8$ & $38.9 \pm 1.6$ & $86.7 \pm 1.7$ & $85.6 \pm 0.5$ \\
\hline $\mathrm{CP}$ & $8.8 \pm 0.5$ & $8.7 \pm 0.5$ & $9.7 \pm 0.4$ & $9.9 \pm 0.1$ \\
\hline $\mathrm{ADF}$ & $27.2 \pm 3.2$ & $23.1 \pm 4.3$ & $4.2 \pm 0.2$ & $3.4 \pm 0.8$ \\
\hline NDF & $43.1 \pm 3.2$ & $41.0 \pm 2.2$ & $8.6 \pm 1.6$ & $8.9 \pm 1.2$ \\
\hline NSC & $40.5 \pm 4.1$ & $42.3 \pm 1.9$ & $76.0 \pm 2.3$ & $75.1 \pm 0.6$ \\
\hline $\mathrm{NE}_{\mathrm{L}}, \mathrm{Mcal} / \mathrm{kg}$ & $1.54 \pm 0.02$ & $1.58 \pm 0.09$ & $2.09 \pm 0.02$ & $2.11 \pm 0.04$ \\
\hline $\mathrm{Ca}$ & $0.24 \pm 0.03$ & $0.23 \pm 0.03$ & $0.04 \pm 0.04$ & $0.02 \pm 0.01$ \\
\hline $\mathrm{P}$ & $0.23 \pm 0.03$ & $0.23 \pm 0.02$ & $0.31 \pm 0.04$ & $0.42 \pm 0.11$ \\
\hline $\mathrm{Mg}$ & $0.20 \pm 0.02$ & $0.19 \pm 0.02$ & $0.14 \pm 0.02$ & $0.16 \pm 0.01$ \\
\hline $\mathrm{K}$ & $1.34 \pm 0.06$ & $1.35 \pm 0.10$ & $0.42 \pm 0.04$ & $0.51 \pm 0.09$ \\
\hline $\mathrm{ERD}^{3}, \%$ & $62.1 \pm 1.7$ & $61.6 \pm 1.7$ & $83.2 \pm 5.1$ & $72.6 \pm 5.1$ \\
\hline
\end{tabular}

\footnotetext{
${ }^{1}$ Amounts are as percentages of DM unless indicated otherwise, based on 3 samples of corn silage and corn grain.

${ }^{2}$ Means and standard deviations $(\mathrm{n}=3)$.

${ }^{3}$ Estimated ruminal disappearance (least squares means and standard errors).
}

these experiments were as genetically similar as possible with the exception of inserted Bt-gene. The similarity in nutrient composition between the Bt-CON and the test hybrids is likely a function of these genetic similarities.

It should be noted that corn silage and grain used in these studies were grown in fields that were maintained as pasture for more than $10 \mathrm{yr}$ before the 1998 cropping season. Therefore, European corn borer pressure was minimal based upon visual observations. As a result, the study provides the maximal opportunity to evaluate dairy cow performance that was due to the presence of the plant transgene without confounding potential differences in nutrient composition due to corn borer pressure and damage.

Agronomic data for experiment 3 indicate similar yields of whole plant silage from RR-GA21 and RRCON corn at 7.85 and $7.49 \pm 0.04$ tonne/ha $(P>0.05)$. The DM content and nutrient compositions were similar for silage and grain derived from the RR-GA21 and RR-CON hybrids (Table 5). The lack of appreciable differences in nutrient profiles allowed for substitution of corn grain or silage from the two sources on an equal percentage basis without affecting nutrient profiles of each TMR (Table 2).

There were no differences in DMI, milk production, milk composition, or efficiency of $4 \%$ FCM milk production between cows fed TMR containing silage and grain from RR-GA21 or RR-CON corn hybrids (Table 6). In contrast, in a previous short-term study, dairy cattle fed glyphosate-tolerant whole soybeans or control soybeans had similar milk production but FCM yield was higher than in cows fed control soybeans, which was likely due to increased DM and energy intake rather than differences in digestibility of the feeds (Hammond et al., 1996). The lack of difference in milk production and composition in the present study is a result of the similarity in nutrient composition of the test corn silage and grain and lack of differences in intake and digestibility. Likewise, digestible energy coefficients were not different between Roundup Ready (RR-GA21) and control corn hybrids fed to crossbred barrows, supporting the ideas that these corns are of similar nutritive value (Gaines et. al., 2001). Performance of beef steers fed RR-GA21 or control corn silage and grain was evaluated over an 85 -d silage feeding phase (90\% silage, $10 \%$ supplement) followed by an 84-d grain (75\% rolled corn, $15 \%$ silage, $10 \%$ supplement) finishing phase (Petty et al., 2001). Average daily gain, DMI, and feed/gain were not affected by corn source during either the silage feeding phase or the finishing phase.

Results from situ analysis support a lack of difference in ruminal digestibility between corn grain from transgenic (Bt-MON810 and RR-GA21) and respective controls (Bt-CON or RR-CON) and a lack difference in digestibility of silage from RR-GA21 and RR-CON (Tables 3 and 5). There was a tendency $(P=0.07)$ for reduced ERD of silage from Bt-MON810 compared with Bt-CON. The reasons for this tendency are not apparent, but these changes are not reflected in differences in DMI or milk production. Estimated ruminal digestibility is numerically similar for silage and grain from RR-GA21 and Bt-MON810 corn. The lack of statistical difference in chemical composition of the feeds an rumen digestion, are consistent with the lack of differences in DMI, milk production, and milk composition when either Bt-MON810 or RR-GA21 corn are fed to lactating cows. Taken together, these data demonstrate 
Table 6. Effect of feeding corn silage and corn grain containing glyphosate tolerant (RR-GA21) and its nontransgenic counterpart (RR-CON) on feed intake, milk production and composition.

\begin{tabular}{lcccc}
\hline & RR-GA21 & RR-CON & SE & $P$-value \\
\hline DMI, kg/d & 21.8 & 21.5 & 0.4 & 0.58 \\
4\% FCM yield, kg/d & 27.8 & 27.5 & 0.4 & 0.58 \\
Milk yield, kg/d & 29.5 & 29.4 & 0.4 & 0.81 \\
Efficiency (Milk:DMI, kg/kg) & 1.30 & 1.29 & 0.02 & 0.89 \\
Milkfat, \% & 3.61 & 3.55 & 0.04 & 0.28 \\
Milkfat, kg/d & 1.06 & 1.04 & 0.02 & 0.47 \\
Milk protein, \% & 3.24 & 3.25 & 0.01 & 0.28 \\
Milk protein, kg/d & 0.96 & 0.96 & 0.01 & 0.98 \\
Milk lactose, \% & 4.72 & 4.70 & 0.01 & 0.37 \\
Milk lactose, kg/d & 1.40 & 1.40 & 0.02 & 0.77 \\
SNF, \% & 8.75 & 8.74 & 0.02 & 0.66 \\
SNF, kg/d & 2.59 & 2.58 & 0.04 & 0.87 \\
SCC (× 10 ${ }^{3}$ cells/ml) & 99 & 101 & 10 & 0.89 \\
BW change, kg & -22.3 & -25.0 & 4.5 & 0.68 \\
BCS change ${ }^{1}$ & -0.06 & -0.13 & 0.03 & 0.07 \\
\hline
\end{tabular}

${ }^{1}$ Units of BCS change based on a 1 point scale where $1=$ thin and $5=$ obese.

a similar feeding value for Bt-MON810 or RR-GA21 corn when compared with their near-isogenic conventional corn hybrids.

Substantial equivalence is an accepted method of evaluating foods by the Food and Agriculture Organization of the United Nations and World Health Organization (Hoover et al., 2000). Substantial equivalence focuses on searching for differences between transgenic plant material and its near-isogenic counterpart that might present safety or nutritional concerns. This concept can be extended to include performance and health of food animals given diets containing feeds derived from transgenic plants. In establishing substantial equivalence it is critical to determine the power of the analysis or the risk of falsely rejecting the null hypothesis when it is true (Netter, 1985) or missing the effect when it really is present. Power of the test for milk yield, DMI, fat yield, and protein yield are 0.87, 0.79, 0.99 , and 0.99 , respectively, using combined data from experiments 1 and 2 . Similar values were obtained from power analysis of experiment 3 . Based on these calculations the experimental design and number of cows used in these experiments was adequate to detect an effect of feeding GM corn on major production variables and feed intake if such an effect existed. These data indicate equivalence of the feeding value for RR-GA21 and BtMON810 corn compared with their respective near-isogenic controls.

In some instances, the effects of transgenic crops to reduce insect damage may reduce secondary pests such as fungi and molds, which result in a higher quality feed (Bakan et al., 2002). Corn grain from Bt-hybrids grown in several countries had substantially reduced levels of mycotoxin contamination compared with control hybrids (Aumaitre et al., 2002). Grains from experiments reported here had mycotoxin levels below detect- able limits or well below levels of concern for animal feed (data not presented).

\section{IMPLICATIONS}

The compositional analysis and feeding data support equivalence of the nutrient composition and feeding value for RR-GA21 and Bt-MON810 corn compared with their respective near-isogenic controls. Feeding value of transgenic corn hybrids for milk production is indistinguishable from nontransgenic hybrids. Benefits in using transgenic corn for dairy cattle may only be observed if environmental conditions (such as insect pressure or weediness) provide an agronomic advantage.

\section{REFERENCES}

Adkisson, P., S. Abramson, S. Baenziger, F. Betz, J. C. Carrigton, R. J. Goldgurg, F. Gould, E. Hodgson, T. Jones. M. Levin, E. Lichtenberg, and A. Snow. 2000. Genetically Modified Pest-Protected Plants : Science and Regulation. National Academy Press, Washington, DC.

Aumaitre, A., K. Aulrich, A. Chesson, G. Flachowsky, and G. Piva. 2002. New feeds from genetically modified plants: Substantial equivalence, nutritional equivalence, digestibility, and safety for animals and the food chain. Livest. Prod. Sci. 74:223-238.

Bakan B, D. Melcion, D. Richard-Molard, and B. Cahagnier. 2002. Fungal growth and fusarium mycotoxin content in isogenic traditional maize and genetically modified maize grown in France and Spain. J. Agric. Food Chem. 50:728-731.

Barriere, Y., R. Verite, P. Brunschwig, F. Surault, and J. C. Emile. 2001. Feeding value of corn silage estimated with sheep and dairy cows is not altered by genetic incorporation of Bt176 resistance to Ostrinia nubilalis. J. Dairy Sci. 84:1863-1871.

Beever, D. E., and C. F. Kemp. 2000. Safety issues associated with the DNA in animal feed derived from genetically modified crops. A review of scientific and regulatory procedures. Nutr. Abstr. Rev.: Livest. Feeds Feeding 70:175.

Clark, J. H., and I. R. Ipharraguerre. 2001. Livestock performance: Feeding biotech crops. J. Dairy Sci. 84 (E. Suppl.):E9-E18. 
Faust, M., and L. Miller. 1997. Study finds no Bt in milk. IC-478. Fall Special Livestock Edition. pp 6-7. Iowa State University Extension, Ames, Iowa.

Feitelson, J. S., J. Payne, and L. Kim. 1992. Bacillus thuringiensis: Insects and beyond. Bio/Technology. 10:271-275.

Folmer, J. D., R. J. Grant, C. T. Milton, and J. Beck. 2002. Utilization of Bt corn residues by grazing beef steers and Bt corn silage and grain by growing beef cattle and lactating dairy cattle. J. Anim. Sci. 80:1352-1361.

Gaines, A. M., G. L. Allee, and B. W. Ratliff. 2001. Swine digestible energy evaluations of Bt (MON810) and Roundup Ready corn compared with commercial varieties. J. Anim. Sci. 79(Suppl. 1):109. (Abstr.)

Hammond, B. G., J. L. Vicini, G. F. Hartnell, M. W. Naylor, C. D. Knight, E. H. Robinson, R. L. Fuchs, and S. R. Padgette. 1996. The feeding value of soybeans fed to rats, chickens, catfish, and dairy cattle is not altered by genetic incorporation of glyphosate tolerance. J. Nutr. 126:717-27.

Hoover, D., B. M. Chassy, R. Hall, H. J. Klee, J. B. Luchansky, H. I. Miller, I. Munro, R. Weiss, S. L. Hefle, and C. O. Qualset. 2000. Human food safety evaluation of rDNA biotechnology-derived foods. Food Technol. 54:15-23.

Koziel, M. G., G. L. Beland, C. Bowman, N. B. Carozzi, R. Crenshaw, L. Crossland, J. Dawson, N. Desai, M. Hill, S. Kadwell, K. Launis, K. Lewis, D. Maddox, K. McPherson, M. R. Meghji, E. Merlin, R. Rhodes, G. W. Warren, M. Wright, and S. V. Evola. 1993. Field performance of elite transgenic maize plants expressing an insecticidal protein derived from Bacillus thuringiensis. Bio/Technology 11:194-200.

Lucas, H. I. 1960. Critical features of good dairy feeding experiments. J. Dairy Sci. 43:193-212.
Mayer, J., and K. Rutzmoser. 1999. Einsatz von silomais herkommlicher sorten und der gentechnisch veranderten Bt-hybriden in der rinderfutterung: bei milchkuhen. 12th Corn Colloquium.

Neter, J., W. Wasserman, and M. H. Kutner. 1985. Applied Linear Statistical Models. 2nd ed. Irwin, Homewood, IL.

Nocek, J. E. 1988. In situ and other methods to estimate ruminal protein and energy digestibility: A review. J. Dairy Sci. 71:2051-2069.

Peferoen, M. 1997. Transgenic maize expressing a Bacillus thuringiensis insecticidal protein for control of European corn borer. Pages 63-74 in Advances in Insect Control: The Role of Transgenic Plants. N. Carozzi and M. Koziel, ed. Taylor and Frances, Bristol, PA.

Petty, A. T., K. S. Hendrix, E. P. Stanisiewski, and G. F. Hartnell. 2001. Performance of beef cattle fed Roundup Ready corn harvested as whole plant silage or grain. J. Anim. Sci. 79(Suppl. 2):102. (Abstr.)

Pilcher, C. D., and M. E. Rice. 1998. Management of European corn borer (Lepidoptera: Crambidae) and corn rootworms (Coleoptera: Chysomelidae) with transgenic corn: A survey of farmer perceptions. Am. Entomol. 44:36-44.

Rice, M. E., and C. D. Pilcher. 1998. Potential benefits and limitations of transgenic Bt corn for management of the European corn borer (Lepidoptera: Crambidae). Am. Entomol. 44:75-78.

SAS Institute SAS/STAT Software Release 8.02. 1999. SAS Inst., Inc., Cary, NC.

Vazquez-Anon, M., A. J. Heinrichs, J. M. Aldrich, and G. A. Varga. 1993. Effect of postweaning age on rate of in situ protein disappearance in calves weaned at 5 weeks of age. J. Dairy Sci. 76:2749-2757.

Wildman, E. E., G. M. Jones, P. E Wagner, R. L. Bowman, H. F. Trout Jr., and T. N. Lesch. 1982. A dairy cow body condition scoring system and its relationship to selected production characteristics. J. Dairy Sci. 65:495-501. 